\title{
Changes in the Volatile Organic Profile of Schinus polygamus (Anacardiaceae) and Baccharis spicata (Asteraceae) Induced by Galling Psyllids
}

\author{
Flaviana C. Damasceno, ${ }^{a}$ Karine P. Nicolli, ${ }^{a}$ Elina Bastos Caramão, ${ }^{a}$ \\ Geraldo L. G. Soares ${ }^{b}$ and Cláudia A. Zini ${ }^{*, a}$ \\ ${ }^{a}$ Laboratório de Química Analítica Ambiental e Oleoquímica, Instituto de Química and \\ ${ }^{b}$ Departamento de Botânica, Instituto de Biociências, Universidade Federal do Rio Grande do Sul, \\ Av. Bento Gonçalves 9500, 91501970 Porto Algre-RS, Brazil
}

\begin{abstract}
Baccharis spicata (Asteraceae) e Schinus polygamus (Anacardiaceae) são plantas nativas do Rio Grande do Sul e são hospedeiras de dois psilídeos galhadores (Hemiptera, Psyllidae) ainda não identificados. As duas plantas em estudo produzem óleo essencial e seus compostos voláteis podem ter um importante papel na interação inseto-planta. A extração e análise dos voláteis das folhas, folhas galhadas e galhas foram realizadas por microextração em fase sólida no modo "headspace" e por cromatografia gasosa com detector de espectrometria de massas. Verificou-se que a composição do "headspace" das galhas de B. spicata e S. polygamus é diferente daquela do "headspace" das folhas sadias. A principal alteração observada foi o aumento da contribuição de monoterpenos no "headspace" das galhas comparativamente ao que se verificou nos tecidos saudáveis. Algumas mudanças também foram observadas na produção de voláteis verdes, em ambas as espécies, mas especialmente na $S$. polygamus. O possível papel ecológico desses compostos químicos também é discutido.
\end{abstract}

Baccharis spicata (Asteraceae) and Schinus polygamus (Anacardiaceae) are plants native from Rio Grande do Sul and are hosts of two unidentified galling psyllids (Hemiptera, Psyllidae). Both plant species produce essential oil and their volatile compounds play an important role related to this kind of plant-insect interaction. Extraction and analysis of volatiles produced by leaves, galled leaves and galls were performed using headspace solid phase microextraction and gas chromatography coupled to mass spectrometry detector. Composition of the headspace of B. spicata and S. polygamus galls showed a significant change in their volatile profile when compared to healthy leaves. These changes were mainly related to a higher production of monoterpenes in galled tissue, compared to what was found in healthy samples. Some changes on the production of green leaf volatiles were also observed in both plant species, especially in S. polygamus. The possible ecological role of these chemical changes was discussed.

Keywords: galls, leaves, Baccharis spicata, Schinus polygamus, headspace solid phase microextraction

\section{Introduction}

Galls are the result of histological alterations in plant organs, mainly hypertrophy and hyperplasy, caused by the activity of an inductor which can be virus, bacteria, nematodes, insects and other plants. These organisms can interfere with the normal development of cells and tissues leading to several physiological and morphological changes. Gall-inducing insects (insect gallmakers) are masters in the art of beguiling or compelling the host plant

\footnotetext{
*e-mail: cazini@iq.ufrgs.br
}

to provide food and shelter with a minimum expenditure of effort on their part and galls induced by insect are one of most diverse plant galls. ${ }^{1}$ Galls are found on all plant organs, such as flowers, leaves, stems and roots. They provide food and shelter to the inducer which lives in a microenvironment relatively safe from natural enemies. ${ }^{2}$ The leaf galls are variable in form and occur in the majority of plant hosts. ${ }^{2}$

Plant volatiles can act as chemical signals to herbivores and its biosynthesis can be changed as a response to herbivory. ${ }^{3,4}$ Some of these metabolites can act as signals to insects for plant host finding and recognition ${ }^{5,6}$ or as attractants to natural enemies. ${ }^{7}$ 
The signaling phenomenon is well known when dealing with free-living herbivore insect. ${ }^{8}$ However, the role of volatile secondary metabolites as signals in plant-galling insect interactions is practically unknown. This kind of herbivore spends a major part of its life cycle into the plant tissues ${ }^{10}$ and apparently do not have behavioral strategies to avoid the effects of the plant defensive metabolites. Among a few published works related to signaling between insect gall makers and their hosts, Flamini and coworkers ${ }^{11}$ reported changes in volatile composition of Pistacia palaestina Boiss (Anacardiaceae) under the attack of Baizongia pistaciae (Homoptera: Aphidoidea).

Baccharis (Asteraceae) posses more than 500 species distributed mainly in the tropical areas of South America. ${ }^{12}$ Approximately 120 of them are found in Brazil and around 70 species are native of Rio Grande do Sul State. ${ }^{13}$ This genus is well-studied and produces a variety of compounds of different structural types. Terpenoids, ${ }^{12,14-15}$ are mainly reported for its pharmacological and biological activity, being widely used in the perfumery industry and traditional medicine. ${ }^{17-19}$ Baccharis spicata is a shrub native of South Brazil, Paraguay, Uruguay and Argentina. There is scarce information on its chemical composition, but $B$. spicata aqueous and ethanol extracts show antioxidant activity and are effective in the prevention of lipid peroxidation by inhibiting the formation of thibarbituric acid reactive species and cell mortality induced by hydrogen peroxide. ${ }^{20}$

Schinus (Anacardiaceae) contains approximately 600 species typical of tropical and subtropical regions. ${ }^{21}$ Schinus spp. are related to contact dermatitis, although only some species contain alkenyl catechols, metabolites with potential allergenic properties. ${ }^{22}$ Schinus polygamus is a thorny bush or a small tree native from Brazil, Argentina, Chile, Uruguay and Peru. Alpha-phellandrene and limonene are the major components of its essential oil, which is reported to present antimicrobial activity. The hexane and methanol extracts of S. polygamus contain $\beta$-sitosterol, quercetin and related compounds, which were associated to analgesic, antiinflammatory and anti-thermal activities. ${ }^{23,24}$

Baccharis spicata and S. polygamus are hosts of galling psyllids (Hemiptera, Psyllidae). In B. spicata, as the inductor (an unidentified species of Baccharopelma) attacks leaves; they are folded upward alongside the midrib and the edges of the upper portion approaching each other, forming a longitudinal slit (Figure 1). All leaf turned into a fusiform gall with a single chamber formed on the adaxial surface of the leaf. This gall is very similar to those induced by Baccharopelma dracunculifoliae in B. drancunculifolia. ${ }^{25}$ Schinus polygamus presents foliar galls induced by an unidentified psyllid species probably belonging to the genera Calophya. ${ }^{26}$ These small conical galls were found dispersed on the leaf blade, which maintains portions of healthy tissue (Figure1). Both species are native of Brazil and belong to plant genera which present volatile organic compounds (VOC) ${ }^{18,24}$ that can act as mediators in the interactions between these plant species and some associated herbivores. ${ }^{9}$ It is possible that these galling herbivores may induce changes in the VOC-profile of these plant hosts. Also, the galling insects which attack S. polygamus and B. spicata are taxonomically related and belong to the same guild of gall makers.

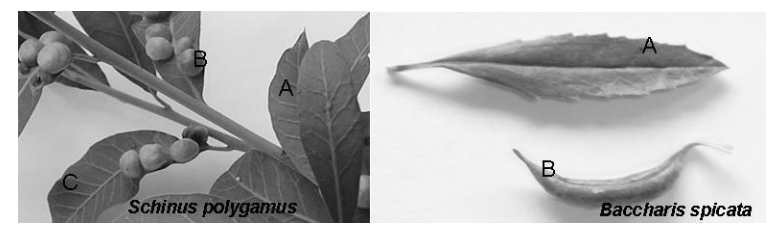

Figure 1. Healthy leaves (A), galls (B) and healthy portion of the galled leaves (C) of the Schinus polygamus and Baccharis spicata.

Headspace solid-phase micro extraction (HS-SPME) has been already employed in the study of fresh plant volatile compounds, as it presents some advantages over other sampling techniques. It is a solvent-free and sensitive technique, in which extraction and concentration are performed in a single step. Moreover, it provides information on the plant composition which is supposed to be closer to the one in vivo. ${ }^{27,28}$

Thus, the aim of the present study was to investigate the changes in chemical composition of volatile components of B. spicata and S. polygamus, possibly elicited by insectplant interaction, using HS-SPME.

\section{Experimental}

Leaves and galls of Schinus polygamus and Baccharis spicata were colleted in Porto Alegre City, State of Rio Grande do Sul, Brazil. Six plants of Baccharis spicata were employed and in the case of Schinus polygamus, only one plant was sampled, as this species is not of widespread occurrence and is usually present as isolated individuals. The samples were identified by a local botanist and voucher specimens of S. polygamus (148777) and B. spicata (148798) have been deposited in the herbarium of the Universidade Federal do Rio Grande do Sul (ICN).

The SPME fiber (DVB-CAR-PDMS 50/30 metal) was provided by Supelco (Bellefonte, PA, USA). Prior to use, the fiber was conditioned according to the supplier specifications. All the $n$-alcanes were purchased from Sigma-Aldrich (Milwaukee, USA) and $\mathrm{Na}_{2} \mathrm{HPO}_{4} /$ $\mathrm{KH}_{2} \mathrm{PO}_{4}$ (sodium phosphate dibasic and potassium dihydrogenphosphate) from Synth (São Paulo, Brazil). 
SPME coating was used for volatile compounds extraction of $0.5 \mathrm{~g}$ of leaves (Figure 1A), galls (Figure 1B) and healthy portion of galled leaves (Figure 1C) of S. polygamus, and leaves (Figure 1A) and galls (Figure 1B) of B. spicata. Leaves, healthy portion of galled leaves and galls were cut (pieces of $c a .2 \mathrm{~mm}^{2}$ ), and placed inside $10 \mathrm{~mL}$ glass vials sealed with PTFE faced septum caps. $4 \mathrm{~mL}$ of a $0.025 \mathrm{~mol} \mathrm{~L}^{-1}$ $\mathrm{Na}_{2} \mathrm{HPO}_{4} / \mathrm{KH}_{2} \mathrm{PO}_{4}$ buffer solution were added to each one of the vials, and then immediately capped and placed on a temperature controlled tray at $30^{\circ} \mathrm{C}$ for approximately $24 \mathrm{~h}$. Headspace extraction was performed for $5 \mathrm{~min}$, and then SPME fiber was immediately inserted into the injection port of the gas chromatograph and kept there at $250{ }^{\circ} \mathrm{C}$ for $15 \mathrm{~min}$. For each tissue type, five vials containing vegetable material were employed in extraction and analysis. Each vial contained 8 to 10 leaves (or galls, $\mathrm{n}=40$ and 50 respectively), with the exception of galls of Baccharis spicata, where 6 galls $(n=30)$ were used. Sampling of vegetable material was performed over the whole canopy of the bush in order to obtain a representative sample.

Linear temperature programmed retention indices (LTPRI) were determined employing retention data of three $n$-alkanes solutions (C9 to C12, C13 to C16 and C17 to $\mathrm{C} 20$ ), along with retention data of volatile compounds of B. spicata and S. polygamus samples. $500 \mu \mathrm{L}$ of $1 \%$ methanolic solutions of $\mathrm{C} 9$ to $\mathrm{C} 12$ and $\mathrm{C} 13$ to $\mathrm{C} 16 n$-alkanes were diluted to $2 \mathrm{~mL}$ of water. The same procedure was adopted to prepare the solution of the $n$-paraffins $\mathrm{C} 17$ to $\mathrm{C} 20$, except the last one when $1000 \mu \mathrm{L}$ was diluted to $2 \mathrm{~mL}$. Headspace extraction was carried out at $30^{\circ} \mathrm{C}$ during $5 \mathrm{~min}$ for the solution of higher molecular weight paraffins and during $1 \mathrm{~min}$ for the two other solutions. Desorption procedure in the injector port was the same described for leaves and galls samples.

A Shimadzu Gas Chromatograph 17A coupled to a Mass Spectrometer Detector QP 5050A (GC/MSD) was employed to perform chromatographic analyses. Capillary column was used under the following conditions: OV-5 $(30 \mathrm{~m} \times 0.25 \mathrm{~mm} \times 0.25 \mu \mathrm{m})$ with initial oven temperature of $60{ }^{\circ} \mathrm{C}$ rising at $3{ }^{\circ} \mathrm{C} \mathrm{min}{ }^{-1}$ until final temperature of $250{ }^{\circ} \mathrm{C}$. Injector and detector temperature were kept at $250{ }^{\circ} \mathrm{C}$, while helium flow rate was $1.0 \mathrm{~mL} \mathrm{~min}^{-1}$ and desorptions were made in the splitless mode. All the components were tentatively identified through comparison of their LTPRI with those registered in the literature databases. ${ }^{29}$ Experimental mass spectra were also compared with the ones stored in MS databases ( $6^{\text {th }}$ edition of the Wiley library). Relative percentage of each component was obtained directly from chromatographic peak areas, considering the sum of all eluted peaks as a hundred percent.
All the extractions and chromatographic analyses were performed in the same period of time, using the same chromatographic and tuning parameters of the mass spectrometer detector to prevent variations due to different detector conditions.

\section{Results and Discussion}

Comparison of volatile profiles in this paper is reported as qualitative differences or changing concentrations, reflecting relative amounts (chromatographic area counts) and not absolute quantities. This is due to the nature of the extraction process employed, considering several equilibria, such as between volatile compounds of small pieces of vegetable tissue and headspace, and between headspace and fiber coating. It is important to point out that even though, in this specific case, HS-SPME may not result in the measure of absolute amounts of volatile compounds, it presents the advantage of measuring the changes in volatile profile of living tissues, which is a difficult goal to reach with other extraction techniques.

Profound changes were found in the composition of healthy and galled leaves of S. polygamus (Figure 2) and B. spicata (Figure 3) and these differences suggest that the presence of galling insects induces changes in the biosynthetic pathways related to these compounds. The main changes were observed mainly in the gall tissue and are related to the mono and sesquiterpenoid compounds. Healthy leaves and healthy tissue of galled leaves showed similar chromatographic profiles for $S$. polygamus volatiles. These data suggest a very specific and highly located stimulus for volatile terpenoid production in both galls. The emission of volatile compounds is controlled by an intricate mechanism coordinated by specific signals and some compounds or mixtures of compounds are clearly emitted after wounding due herbivore feeding. ${ }^{30}$ These plant volatiles play an important ecological role as attractors of pollinators, natural enemies of herbivores and as direct defense compounds. ${ }^{31}$ Plant species commonly produce a great variety of volatiles after herbivore damage, and has been demonstrated that these substances can act as indirect or direct plant defenses. ${ }^{32}$ Considering the results of this work, a valid hypothesis is that psyllid galls will have an impact over S. polygamus and B. spicata, changing their signaling ability.

Linear hydrocarbons $n$-heptane and $n$-nonane were the major components (Table 1) of the headspace of healthy leaves and of the healthy portion of galled leaves of S. polygamus, representing 38.2 and $24.4 \%$ of the total peak areas of the chromatograms, respectively. Besides these two components, another major compound was $\alpha$-pinene, which 


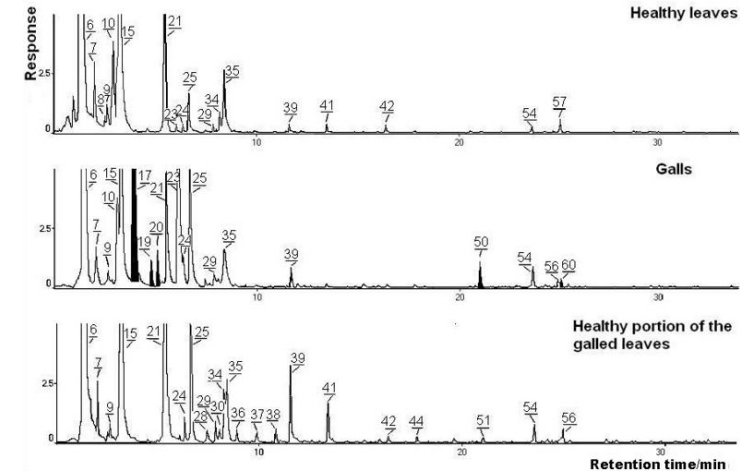

Figure 2. Chromatograms of volatile compounds of the headspace of healthy leaves, healthy portion of galled leaves and galls of Schinus polygamus. The numbers in all chromatograms are in accordance with Tables 1 and 2 and represent the following compounds: 6 . $n$-heptane, 15. $n$-nonane, 17. $\alpha$-pinene, 19. $\beta$-pinene, 20. myrcene, 21. cis-3-hexenyl acetate, 23. limonene, 24. $\Delta$-3-carene, 25 . (Z)- $\beta$-ocimene, 28 . $n$-octanol, 35. $n$-undecane, 39. cis-3-hexenyl butanoato, 50. cis- $\alpha$-bergamotene, 51. (E)-caryophyllene, 54. $\gamma$-muurolene, 56. $(E, E)$ - $\alpha$-farnesene, 60. $\gamma$-cadinene, others: non-identified compounds. Shaded areas indicate compounds detected only in galls.

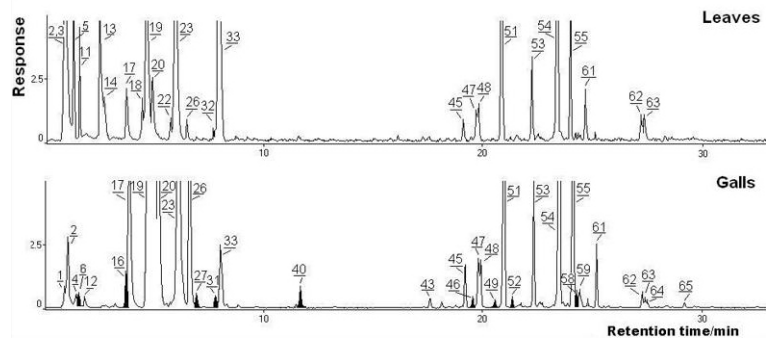

Figure 3. Chromatograms of volatile compounds of the headspace of leaves and galls of Baccharis spicata. The numbers in all chromatograms are in accordance with Tables 1 and 2 and represent the following compounds: 6. $n$-heptane, 13. (E)-3-hexenol, 16. thujene, 17. $\alpha$-pinene, 18. sabinene, 19. $\beta$-pinene, 20. myrcene, 22. o-cymene, 23. limonene, 26. (E)- $\beta$-ocimene, 27. $\gamma$-terpinene, 31. terpinolene, 33. 1-undecene, 40. $\alpha$-terpineol, 45. $\alpha$-copaene, 46. $\beta$-bourbonene, 47. $\beta$-cubebene, 48. $\beta$-elemene, 49. $\alpha$-gurjunene, 51 . (E)-caryophyllene, 52. $\beta$-gurjunene, 53. $\alpha$-humulene, 54. $\gamma$-muurolene, 55. bicyclogermacrene, 58. germacrene A, 61. $\delta$-cadinene, 62. spathulenol, 63. caryophyllene oxide, others: non-identified. Shaded areas indicate compounds detected only in galls.

was found in the galls of S. polygamus (17.6\% of the total peak area) and was not detected in the headspace of healthy leaves.

Among all volatile terpenoids present in galls of both species, $\alpha$-pinene stands out as one of the major compounds of $S$. polygamus galls. This monoterpene presents allelopathic properties ${ }^{33}$ and may act as ovipositional signaling for herbivore insects. One example of its stimulant activity was reported for the oviposition of Dioryctria amatella (Lepidoptera: Pyralidae). $\alpha$-Pinene metabolites produced by Ips pini (Coleoptera: Scolytidae) play a role in the complex population control of this beetle, as they act as repellents of other males of the same species. ${ }^{5,9,34}$

Some other compounds were also detected only in the headspace of S. polygamus galls and not in the headspace of healthy leaves or healthy parts of the leaves, such as the monoterpenes $\beta$-pinene $(0.2 \%)$ and myrcene $(0.4 \%)$, and the sesquiterpenes cis- $\alpha$-bergamotene $(0.8 \%)$ and $\gamma$-cadinene $(0.1 \%)$ (Table 2). An interesting change in the volatile profile of S. polygamus was the enhancement of limonene area percentage in the headspace of galls. This monoterpene was not detected in the headspace of the healthy part of galled leaves and was found as a trace compound in the headspace of healthy leaves $(0.1 \% \pm 0.03)$. However it showed up as a major compound of the galls headspace $(5.4 \% \pm 1.3)$. Figure 4 shows a higher amount of terpenoids extracted from the headspace of galled $(29.7 \pm 3.8)$ tissue compared with normal tissue $(1.5 \pm 0.3)$. All these differences among VOC composition may suggest changes in the biosynthetic route due to tissue transformation associated with the presence of the gallmaker.

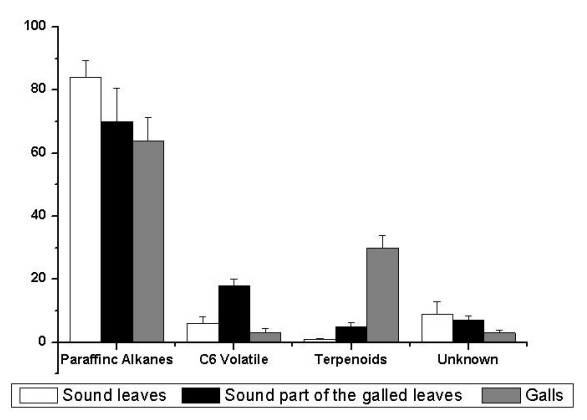

Figure 4. Percentual average of chromatographic peak areas of parafins, green leaf volatiles (presenting 6 carbons in the molecule), terpenoid and non-identified compounds of different tissues of Schinus polygamus.

In general, regarding B. spicata, a higher amount of VOC was found in the headspace of galled leaves (33 compounds). The major ones were: monoterpenes $\beta$-pinene (40.9\%) and limonene (19.1\%), while healthy leaves provided 25 compounds, presenting 1-undecene (17.8\%), limonene (15.3\%), $\beta$-pinene (13.5\%), (E)-caryophyllene $(12.8 \%)$ and $\gamma$-muurolene $(11.4 \%)$ as the major ones, according to Table 1. $n$-Heptane, $\alpha$-thujene, $\gamma$-terpinene, terpinolene, $\alpha$-terpineol, $\beta$-bourbunene, $\alpha$-gurjunene, $\beta$-gurjunene and germacrene A were found only in the headspace of galls, even though they were present in lower concentrations (Table 2). The occurrence of these compounds solely in the headspace of galls may be strongly related to the gallmaker activity.

Likewise S. polygamus, terpenoid compounds presented higher concentrations in the headspace of the tissue attacked by the gallmaker ( $96 \pm 1.1$ for galls and $68 \pm 8.2$ for healthy leaves), and this phenomenon can be observed in Figure 5.

$\alpha$-Terpineol is a trace volatile compound found only in the headspace of B. spicata galls. In spite of its low concentration this compound can act as a barrier against herbivores that would attack gall tissues. Lee and 
Table 1. Major volatile organic compounds (> 1\%) in healthy and galled leaves of Schinus polygamus and Baccharis spicata

\begin{tabular}{|c|c|c|c|c|c|}
\hline \multirow{2}{*}{ Compound } & \multicolumn{3}{|c|}{ Schinus polygamus } & \multicolumn{2}{|c|}{ Baccharis spicata } \\
\hline & $\mathrm{HL}^{\mathrm{a}}$ & $\mathrm{HPGL}^{\mathrm{b}}$ & gall & $\mathrm{HL}^{\mathrm{a}}$ & gall \\
\hline Parafinic alkane & $\begin{array}{c}n \text {-heptane (6) } \\
(701,700) \\
n \text {-nonane }(15) \\
(900,900) \\
n \text {-undecane }(35) \\
(1097,1100)\end{array}$ & $\begin{array}{c}n \text {-heptane }(6) \\
(701,700) \\
n \text {-nonane }(15) \\
(900,900) \\
n \text {-undecane }(35) \\
(1097,1100)\end{array}$ & $\begin{array}{c}n \text {-heptane }(6) \\
(701,700) \\
n \text {-nonane }(15) \\
(900,900) \\
n \text {-undecane }(35) \\
(1097,1100)\end{array}$ & $\begin{array}{l}\text { 1-undecene (33) } \\
(1089,1087)\end{array}$ & $\begin{array}{l}\text { 1-undecene (33) } \\
(1089,1087)\end{array}$ \\
\hline Monoterpene & $\begin{array}{c}(Z)-\beta \text {-ocimene }(25) \\
(1041,1037)\end{array}$ & $\begin{array}{c}(Z)-\beta \text {-ocimene }(25) \\
(1041,1037)\end{array}$ & $\begin{array}{c}\alpha \text {-pinene }(17) \\
(930,939) \\
\text { limonene }(23) \\
(1023,1029) \\
(Z)-\beta \text {-ocimene }(25) \\
(1041,1037)\end{array}$ & $\begin{array}{l}\alpha \text {-pinene (17) } \\
(930,939) \\
\beta \text {-pinene (19) } \\
(973,979) \\
\text { myrcene (20) } \\
(987,991) \\
\text { limonene (23) } \\
(1024,1029)\end{array}$ & $\begin{array}{c}\alpha \text {-pinene }(17) \\
(930,939) \\
\beta \text {-pinene }(19) \\
(973,979) \\
\text { myrcene }(20) \\
(987,991) \\
\text { limonene }(23) \\
(1024,1029) \\
(E)-\beta \text {-ocimene }(26) \\
(1043,1050)\end{array}$ \\
\hline Sesquiterpene & - & - & - & $\begin{array}{c}(E) \text {-caryophyllene }(51) \\
(1413,1419) \\
\alpha \text {-humulene }(53) \\
(1448,1455) \\
\gamma \text {-muurolene }(54) \\
(1475,1480) \\
\text { bicyclogermacrene }(55) \\
(1493,1500)\end{array}$ & $\begin{array}{c}(E) \text {-caryophyllene }(51) \\
(1413,1419) \\
\alpha \text {-humulene }(53) \\
(1448,1455) \\
\gamma \text {-muurolene }(54) \\
(1475,1480) \\
\text { bicyclogermacrene }(55) \\
(1493,1500)\end{array}$ \\
\hline Others & $\begin{array}{l}\text { cis-3-hexenyl acetate } \\
\text { (21) }(1002,1005)\end{array}$ & $\begin{array}{c}\text { cis-3-hexenyl acetate } \\
\text { (21) }(1002,1005) \\
\text { cis-3-hexenyl butanoate } \\
\text { (39) }(1181,1186)\end{array}$ & $\begin{array}{l}\text { cis-3-hexenyl acetate } \\
\text { (21) }(1002,1005)\end{array}$ & $\begin{array}{c}(E)-3 \text {-hexenol }(13) \\
(849,854)\end{array}$ & - \\
\hline
\end{tabular}

${ }^{\mathrm{a}} \mathrm{HL}$ healthy leaves; ${ }^{\mathrm{b}} \mathrm{HPGL}$ healthy part of galled leaves; numbers between parenthesis after compound name designates the peak of the compound in Figures 2 and 3; numbers between parenthesis below compound names are: retention index obtained experimentally, retention index from the scientific literature. ${ }^{26}$

coworkers ${ }^{35}$ showed that the $\alpha$-terpineol, in a very low concentration $\left(\mathrm{DL}_{50}=112 \mu \mathrm{g} \mathrm{mL}^{-1}\right)$, can protect corn roots against the attack of Diabrotica virgifera virgifera (Coleoptera: Chrysomelidae) larvae.

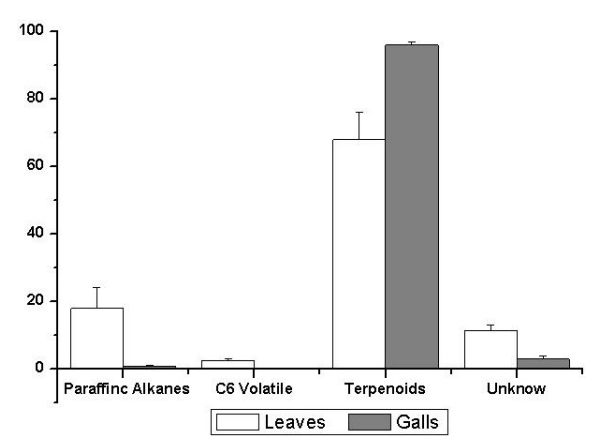

Figure 5. Percentual average of chromatographic peak areas of parafins, green leaf volatiles (presenting 6 carbons in the molecule), terpenoid and non-identified compounds of different tissues of Baccharis spicata.

$\alpha$-cis-Bergamotene is a trace volatile detected only in $S$. polygamus galls. This compound can protect gall tissues against herbivores because it possibly acts as an attractant for predators. This action of $\alpha$-cis-bergamotene was observed in specimens of Nicotiana attenuate (Solanaceae) attacked by Manduca quinquemaculata (Lepidoptera: Sphingidae). The oral secretion of this insect can stimulate the production of small amounts of $\alpha$-cis-bergamotene, which attracts predator insects. This stimulus is similar to the one promoted by methyl jasmonate. ${ }^{36}$

Among all volatile terpenoids present in galls of both species, $\alpha$-pinene stands out as one of the major compounds of $S$. polygamus galls. This monoterpene presents allelopathic properties ${ }^{33}$ and may act as ovipositional signaling for herbivore insects. One example of its stimulant activity was reported for the oviposition of Dioryctria amatella (Lepidorptera: Pyralidae). $\alpha$-Pinene metabolites produced by Ips pini (Coleóptera: Scolytidae) play a role in the complex population control of this beetle, as they act as repellents of other males of the same species. . $9,34^{3}$

$\beta$-Pinene also appears as a signal related to the psyllid gall induction in both plant models analyzed in this work. This monoterpene was detected in the headspace of the galls of $S$. polygamus, but was not detected in the headspace of healthy leaves or in the headspace of healthy parts of galled leaves of this plant species. On other hand, $\beta$-pinene 
Table 2. Minor volatile organic compounds $(<1 \%)$ in healthy and galled leaves of Schinus polygamus and Baccharis spicata

\begin{tabular}{|c|c|c|c|c|c|}
\hline \multirow{2}{*}{ Compound } & \multicolumn{3}{|c|}{ Schinus polygamus } & \multicolumn{2}{|c|}{ Baccharis spicata } \\
\hline & $\mathrm{HL}^{\mathrm{a}}$ & HPGL $^{\mathrm{b}}$ & gall & $H^{a}$ & gall \\
\hline Parafinic alkane & - & - & - & - & $\begin{array}{l}n \text {-heptane }(6) \\
(701,700)\end{array}$ \\
\hline Monoterpene & $\begin{array}{c}\text { limonene }(23) \\
(1023,1029)\end{array}$ & - & $\begin{array}{c}\beta \text {-pinene (19) } \\
(971,979) \\
\text { myrcene (20) } \\
(986,991)\end{array}$ & $\begin{array}{c}\text { sabinene }(18) \\
(969,975) \\
(o) \text {-cymene }(22) \\
(1020,1026) \\
(E)-\beta \text {-ocimene }(26) \\
(1043,1050)\end{array}$ & $\begin{array}{c}\alpha \text {-thujene }(16) \\
(923,930) \\
\gamma \text {-terpinene }(27) \\
(1053,1060) \\
\text { terpinolene }(31) \\
(1082,1089) \\
\alpha \text {-terpineol (40) } \\
(1187,1189)\end{array}$ \\
\hline Sesquiterpene & $\begin{array}{c}\gamma \text {-muurolene (54) } \\
(1474,1480)\end{array}$ & $\begin{array}{c}(E) \text {-caryophyllene }(51) \\
(1412,1419) \\
\gamma \text {-muurolene }(54) \\
(1474,1480) \\
(E, E)-\alpha \text {-farnesene }(56) \\
(1505,1506)\end{array}$ & $\begin{array}{c}\alpha \text {-cis-bergamotene (50) } \\
(1410,1413) \\
\gamma \text {-muurolene }(54) \\
(1474,1480) \\
(E, E) \text { - } \alpha \text {-farnesene }(56) \\
(1505,1506) \\
\gamma \text {-cadinene }(60) \\
(1518,1514)\end{array}$ & $\begin{array}{c}\alpha \text {-copaene }(45) \\
(1371,1377) \\
\beta \text {-cubebene }(47) \\
(1385,1388) \\
\beta \text {-elemene }(48) \\
(1388,1391) \\
\delta \text {-cadinene }(61) \\
(1518,1523) \\
\text { spathulenol }(62) \\
(1572,1578) \\
\text { caryophyllene oxide }(63) \\
(1575,1583)\end{array}$ & $\begin{array}{c}\alpha \text {-copaene }(45) \\
(1371,1377) \\
\beta \text {-bourbonene }(46) \\
(1380,1388) \\
\beta \text {-cubebene }(47) \\
(1385,1388) \\
\beta \text {-elemene }(48) \\
(1388,1391) \\
\alpha \text {-gurjenene }(49) \\
(1405,1410) \\
\beta \text {-gurjenene }(52) \\
(1426,1434) \\
\text { germacrene A (58) } \\
(1501,1509) \\
\delta \text {-cadinene (61) } \\
(1518,1523) \\
\text { spathulenol (62) } \\
(1572,1578) \\
\text { caryophyllene oxide (63) } \\
(1575,1583)\end{array}$ \\
\hline Others & $\begin{array}{l}\text { cis-3-hexenyl butanoate } \\
\text { (39) }(1181,1186)\end{array}$ & $\begin{array}{c}n \text {-octanol (28) } \\
(1067,1068)\end{array}$ & $\begin{array}{l}\text { cis-3-hexenyl butanoate } \\
\text { (39) }(1181,1186)\end{array}$ & - & - \\
\hline
\end{tabular}

${ }^{\mathrm{a}} \mathrm{HL}$ healthy leaves; ${ }^{\mathrm{b}} \mathrm{HPGL}$ healthy part of galled leaves; numbers between parenthesis after compound name designates the peak of the compound in Figures 2 and 3 ; numbers between parenthesis below compound names are: retention index obtained experimentally, retention index from the scientific literature. ${ }^{26}$

was detected in the headspace of healthy leaves and galls of B. spicata but showed a three times increase in galled tissues (from $13.5 \pm 3.7$ to $40.9 \pm 4.4$ ). The induction of galls in Silphium lacinatum L. (Asteraceae) by Antistrophus rufus (Hymenoptera: Cynipidaea) was recently associated to changes in enantiomeric ratios of $\alpha$ - and $\beta$-pinene which act as oviposition signals. ${ }^{6}$ Although the role of monoterpenes as reproductive signals to galling psyllid is not yet known, data presented in this work may give a clue about this issue regarding gall induction in S. polygamus and B. spicata.

Myrcene was another monoterpene detected in $S$. polygamus only in the galls headspace. In B. spicata, its presence was observed in the headspace of galls and healthy leaves, although its concentration was higher for gall tissue (from $2.2 \% \pm 0.4$ to $6.6 \% \pm 0.8$ ).

Some previous works showed that monoterpenes probably act as effective barriers against free living herbivore insects. As an example, food enriched with a mixture of $\alpha$-pinene, $\beta$-pinene, limonene and myrcene can reduce the digestive efficiency of Spodoptera litura (Lepidoptera: Noctuidae). ${ }^{37}$ Limonene can act as an insecticide for Rhyzopertha dominica (Coleoptera: Bostrichidae) and Tribolium castaneum (Coleoptera: Tenebrionidae). ${ }^{38}$

A variation in concentration of green leaf volatiles (GLV) was found in both species B. spicata and S. polygamus. As an example, a lower amount of cis-3-hexenyl acetate was detected in the galls headspace of $S$. polygamus when compared to healthy leaves (Figures 2 and 4). However, a significant increase was seen in the headspace of the healthy part of galled leaves $(15.9 \% \pm 2.0)$ of this species in contrast with its healthy leaves $(5.7 \% \pm 1.2)$ and galls $(2.6 \% \pm 0.8)$. The volatile profile of the headspace of healthy leaves and of healthy portions of galled leaves of S. polygamus were very similar. However, the amount of cis-3-hexenyl acetate increased roughly three times in the headspace of the healthy portion of galled leaves when compared to healthy leaves, being lower in galls headspace. Its behavior may be related to its signaling role. 
Low weight aliphatic derivatives from plants, such as $\mathrm{C}_{6}$ alcohols, aldehydes and acetates are commonly named "green leaf volatiles" (GLVs). Despite their simple molecular structure, they have an important role in plantinsect interaction. These compounds stimulate intact plants to produce jasmonic acid, induce defense-related gene expression, and the release of volatile compounds such as monoterpenoids and sesquiterpenoids. ${ }^{39}$ cis-3-Hexenyl acetate can act as an attractant to parasitoids that attack herbivore insects. ${ }^{36,40}$ This observation is consistent with field observations made during the present work, as Schinus polygamus galls were frequently found with parasitoid wasps larvae.

Therefore, a reasonable hypothesis for changes in the volatile profile of $S$. polygamus and B. spicata is that it increases the defenses of these plant species. In fact, during this study, no free living insect was found eating the leaves of these species and the only signal of herbivory found was restricted to the galls. It must be notice that S. polygamus showed several phytosanitary problems (herbivore and pathogens attack) during the period of absence of foliar galls. Also, headspace of healthy leaves of $S$. polygamus showed a very poor volatile profile with low amounts of monoterpenes and high amounts of paraffinic hydrocarbons.

Analytical methods commonly employed for the study of volatile compounds in plants, such as distillation and dynamic headspace would be difficult to apply in this type of investigation, because they either employ harsh experimental conditions for living plants or time consuming and cumbersome procedures. ${ }^{6,11}$ Psyllids are very tiny species and are obligatory parasites, i.e., need the plant hosts in the majority of its life cycle. ${ }^{26}$ Traditional chemoecological tests are not appropriate to investigate these galling species. The use of HS-SPME proved to be a rapid and easy analytical tool, giving access to important information related to signaling mechanisms of this kind of plant-insect interaction.

\section{Conclusions}

Profound changes were observed in the volatile profile of the headspace of leaves of Schinus polygamus and Baccharis spicata as they underwent the attack of galling psyllids. These changes were mainly related to higher production of volatile terpenes in the galled tissues of both species. Also, an increase in the amounts of green volatiles in the vicinity of galls of $S$. polygamus was observed. These chemical changes seem to be linked to the signaling mechanisms of these plant gall models and can provide clues for a better understanding of this complex kind of insect-plant interaction. HS-SPME proved to be an important and unique analytical tool to this specific application because it provided a fast and easy analytical method to access the volatiles profile of minor amounts of living leaves and galls of both investigated species.

\section{Acknowledgments}

We are grateful to Supelco North America for providing the SPME fibers. We also thank CNPq, CAPES and FAPERGS for providing scholarships to F. C. Damasceno and K. P. Nicolli. Dr. Nelson Matzenbacher is specially acknowledged for helping with $S$. polygamus sampling.

\section{Supplementary Information}

Supplementary information is available free of charge at http://jbcs.org.br, as PDF file.

\section{References}

1. Felt, E. P.; Plant Galls and Gall Makers, Updesh Purohit for Agrobios: Jodspur, India, 2001.

2. Ronquist, F.; Liljeblad, J.; Evolution 2001, 55, 2503.

3. Valladares, G. R.; Zapata, A.; Zygadlo, J.; Banchio, E.; J. Agric. Food Chem. 2002, 50, 4059.

4. Banchio, E.; Zygadlo, J.; Valladares, G. R.; J. Chem. Ecol. 2005, 31,719 .

5. Hanula, J. L.; Berisford, C. W.; Debarr, G. L.; J. Chem. Ecol. 1985, 11, 943 .

6. Tooker, J. F.; Hanks, L. M.; J. Chem. Ecol. 2004, 30, 473.

7. James, D. G.; J. Chem. Ecol. 2005, 31, 481.

8. Dicke, M.; Bruin, J.; Sabelis, M. W.; Herbivore-Induced Plant Volatiles Mediate Plant-Carnivore, Plant-Herbivore and PlantPlant Interactions: Talking Plant Revisited, American Society of Plant Physiologists: Rockville, Mayland, 1993.

9. Rosenthal, G. A.; Berenbaum, M. R.; Herbivores their Interactions with Secondary Plant Metabolites, Academic Press Inc: San Diego, California, 1992.

10. Mani, M. S.; The Ecology of Plant Galls, Junk: The Hague, NL, 1964.

11. Flamini, G.; Bader, A.; Cioni, P. L.; Katbeh-Bader, A.; Morelli, I.; J. Agric. Food Chem. 2004, 52, 572.

12. Verdi, L. G.; Brighente, I. M. C.; Pizzolatti, M. G.; Quim. Nova 2005, 28, 85.

13. Oliveira, S. Q.; Barbon, G.; Gosmann, G.; J. Liq. Chromatogr. Relat. Technol. 2006, 29, 2603.

14. Retta, D.; Gattuso, M.; Gattuso, S.; Lira, P. D. L.; van Baren, C.; Bandoni, A.; J. Braz. Chem. Soc. 2009, 20, 1379.

15. Schossler, P.; Schneider, G. L.; Wunsch, D.; Soares, G. L. G.; Zini, C. A.; J. Braz. Chem. Soc. 2009, 20, 277. 
16. Silva, F. G.; Oliveira, C. B. A.; Pinto, J. E. B. P.; Nascimento, V. E.; Santos, S. C.; Seraphin, J.C.; Ferri, P. H. J. Braz. Chem. Soc. 2007, 18, 990.

17. Cassel, E.; Frizzo, C. D.; Vanderlinde, R.; Atti-Serafini, L.; Lorenzo, D.; Dellacassa, E.; Ind. Eng. Chem. Res. 2000, 39, 4803.

18. Vargas, R. M. F.; Cassel, E.; Gomes, G. M. F.; Longhi, L. G. S.; Atti-Serafini, L.; Atti-Santos, A. C.; Braz. J. Chem. Eng. 2006, 23,375 .

19. Faini, F.; Labbé, C.; Coll, J.; Biochem. Syst. Ecol. 1999, 27, 673.

20. Oliveira, S. Q.; Dal-Pizzo, F.; Moreira, J. C. F.; Schenkel, E. P.; Gosmann, G.; Acta Farm. Bonaerense 2004, 23, 365.

21. Kato, E. T. M.; Akisue, G.; Revta. Lecta 2002, 20, 69.

22. Alé, S. I.; Ferriera, F.; González, G.; Epstein, W.; Am. J. Contact Derm. 1997, 8, 144.

23. González, S.; Guerra, P. E.; Bottaro, H.; Morales, S.; Demo, M. S.; Oliva, M. M.; Zunino, M. P.; Zygadlo, J. A.; Flavour Fragr. J. 2004, 19, 36.

24. Erazo, S.; Delporte, C.; Negrete, R.; García, R.; Zaldívar, M.; Iturra, G.; Caballero, E.; López, J. L.; Backhouse, N.; J. Ethnopharmacol. 2006, 107, 395.

25. Arduin, M.; Fernandes, G. W.; Kraus, J. E.; Braz. J. Biol. 2005, 65, 559.

26. Burckhardt, D.; Basset, Y.; J. Nat. Hist. 2000, 34, 57.

27. Zini, C. A.; Augusto, F.; Christensen, E.; Caramão, E. B.; Pawliszyn, J.; J. Agric. Food Chem. 2002, 50, 7199.
28. Zini, C. A.; Zanin, K. D.; Christensen, E.; Caramão, E. B.; Pawliszyn, J.; J. Agric. Food Chem. 2003, 51, 2679.

29. Adams, R. P.; Identification of Essential Oil Components by Gas Chromatography/Quadrupole Mass Spectroscopy, Allured Publishing Corporatin: Carol Stream, Illinois, 2001.

30. Bouvier, F.; Rahier, A.; Camara, B.; Prog. Lipid Res. 2005, 44, 357.

31. Gang, D. R.; Annu. Rev. Plant. Biol. 2005, 56, 301.

32. Dudareva, N.; Pichersky, E.; Gershenzon, J.; Plant Physiol. 2004, 135, 1893

33. Nishida, N.; Tamotsu, S.; Nagata, N.; Saito, C.; Sakai, A.; J. Chem. Ecol. 2005, 31, 1187.

34. Harborne, J. B.; Introduction to Ecological Biochemistry, Academic Press Inc: London, 1993.

35. Lee, S.; Tsao, R.; Peterson, C.; Coats, J. R.; J. Econ. Entomol. 1997, 90, 883.

36. Kessler, A.; Baldwin, I. T.; Science 2001, 291, 2141.

37. Mukherjee, S.; Invert. Reprod. Develop. 2003, 43, 125.

38. Prates, H. T.; Santos, J. P.; Waquil, J. M.; Fabris, J. D.; Oliveira, A. B.; Foster, J. E.; J. Stored Prod. Res. 1998, 34, 243.

39. Yan, Z.-G.; Wang, C.-Z.; Phytochemistry 2006, 67, 34.

40. Chen, L.; Fadamiro, H. Y.; Bull. Entomol. Res. 2007, 97, 1.

Received: October 7, 2009 Web Release Date: December 21, 2009 


\section{Changes in the Volatile Organic Profile of Schinus polygamus (Anacardiaceae) and Baccharis spicata (Asteraceae) Induced by Galling Psyllids}

\section{Flaviana C. Damasceno, ${ }^{a}$ Karine P. Nicolli, ${ }^{a}$ Elina Bastos Caramão, ${ }^{a}$ Geraldo L. G. Soares ${ }^{b}$ and Cláudia A. Zini*,a}

${ }^{a}$ LAAO, Laboratório de Química Analítica Ambiental e Oleoquímica, Instituto de Química and ${ }^{b}$ Departamento de Botânica, Instituto de Biociências, Universidade Federal do Rio Grande do Sul, Av. Bento Gonçalves 9500, 91501970 Porto Algre-RS, Brazil

Mass spectra of compounds that were tentatively identified using retention índices and mass spectra comparison, having retention indices and mass spectra database of standard compounds (Wiley, $6^{\text {th }}$ edition) as standards. Percentages report the similarity between mass spectra of the standard compound found in the Wiley mass spectra library and the one found in the headspace of the plant.

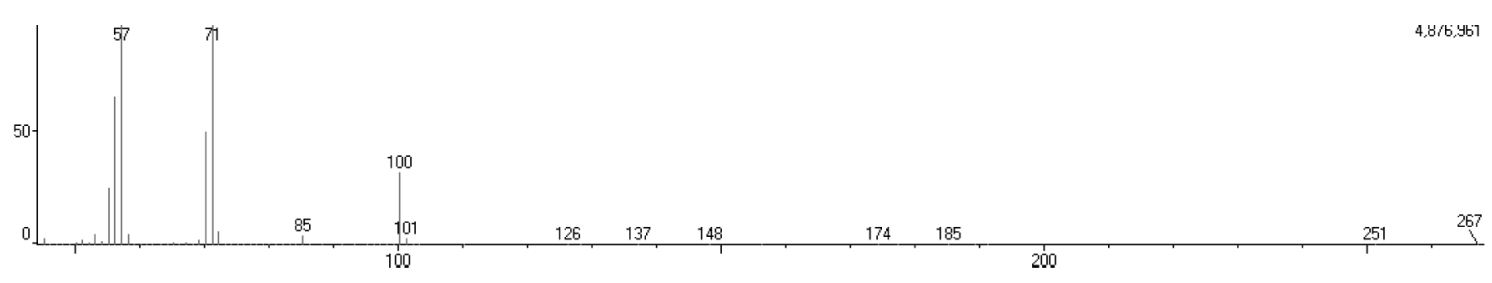

Figure S1. Compound 6, $n$-heptane (97\%).

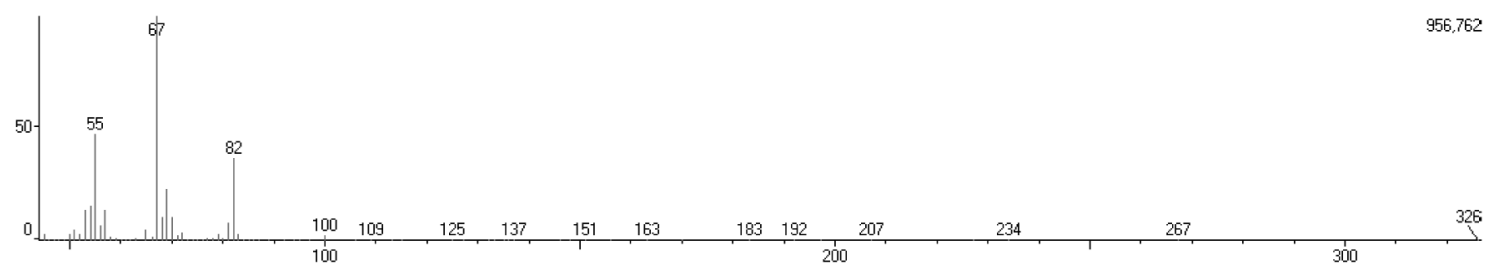

Figure S2. Compound 13, (E)-3-hexenol (94\%).

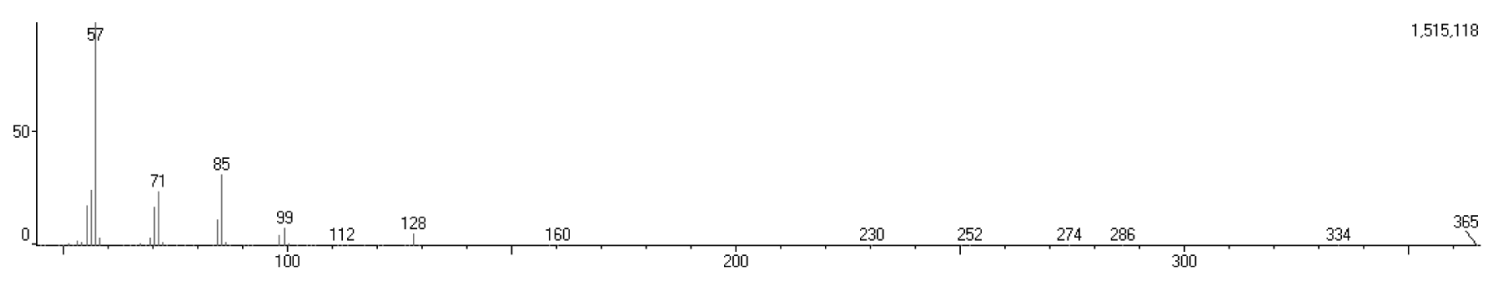

Figure S3. Compound 15, n-nonane (97\%). 


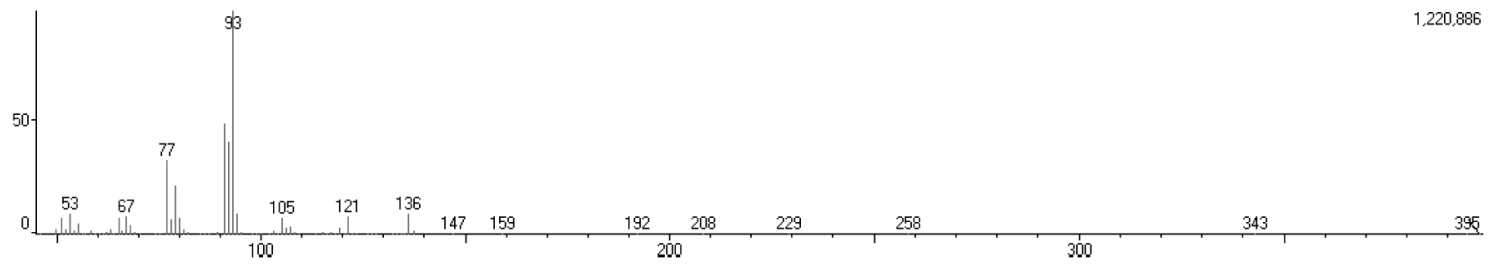

Figure S4. Compund 16, thujene (93\%).

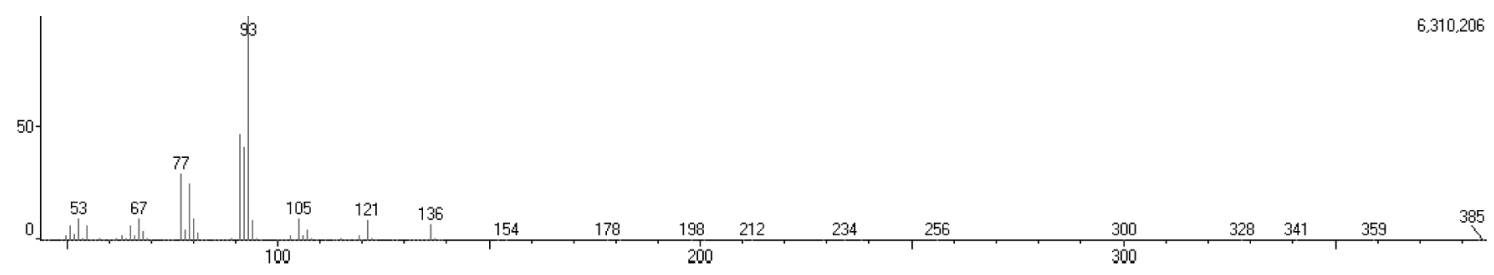

Figure S5. Compound 17, $\alpha$-pinene (98\%).

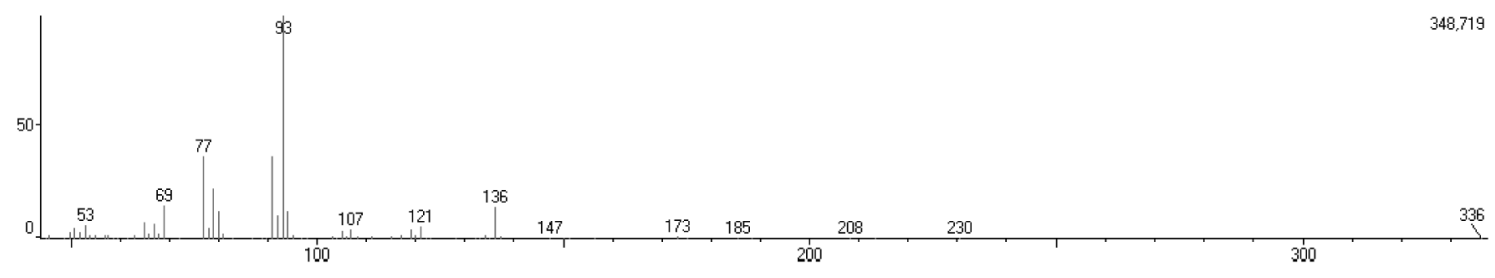

Figure S6. Compound 18, sabinene (94\%).

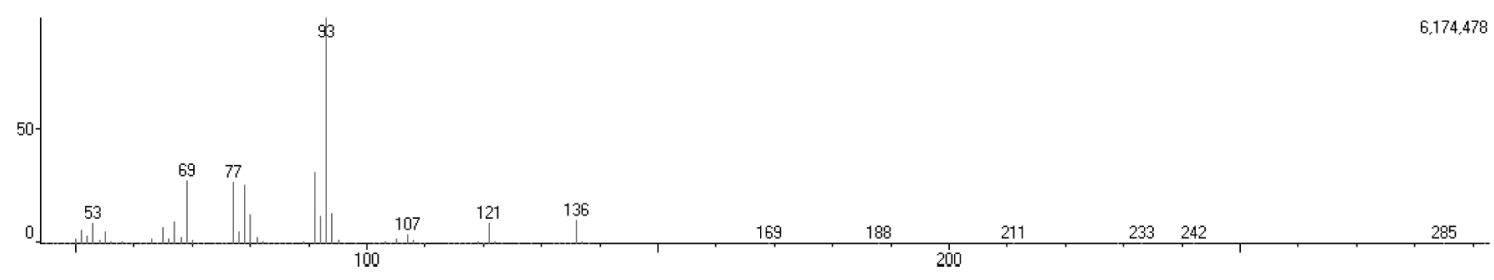

Figure S7. Compound 19, $\beta$-pinene (97\%).

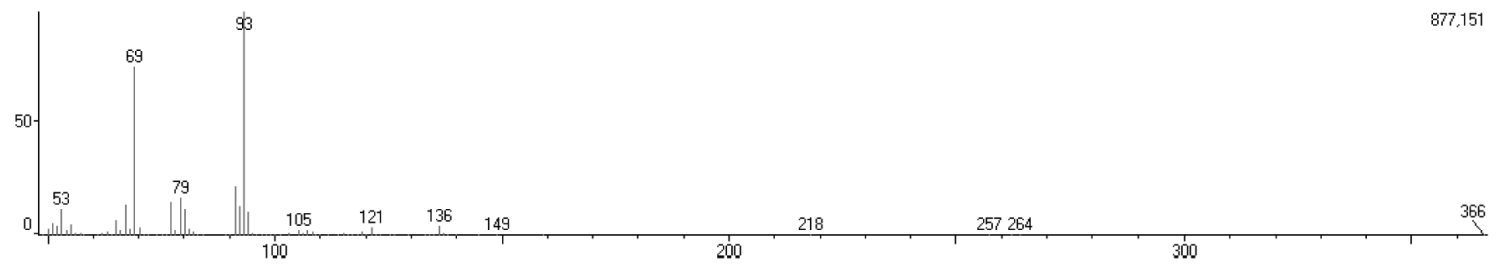

Figure S8. Compound 20, myrcene (97\%). 


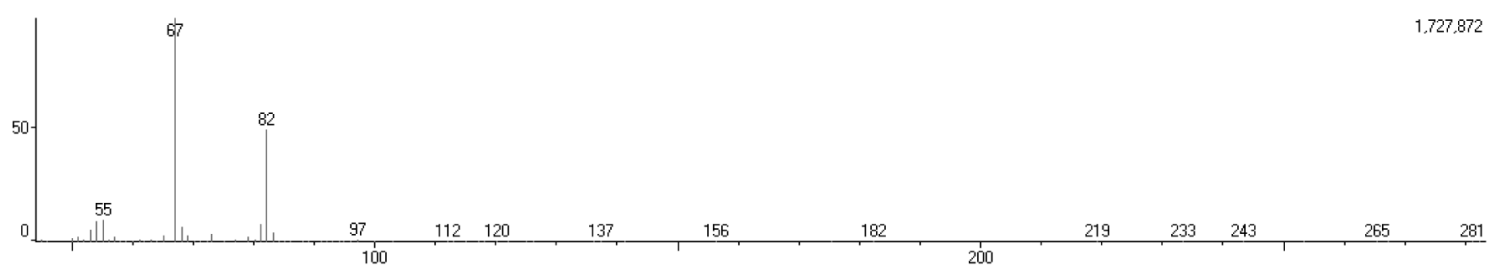

Figure S9. Compound 21, cis-3-hexenyl acetate (96\%).

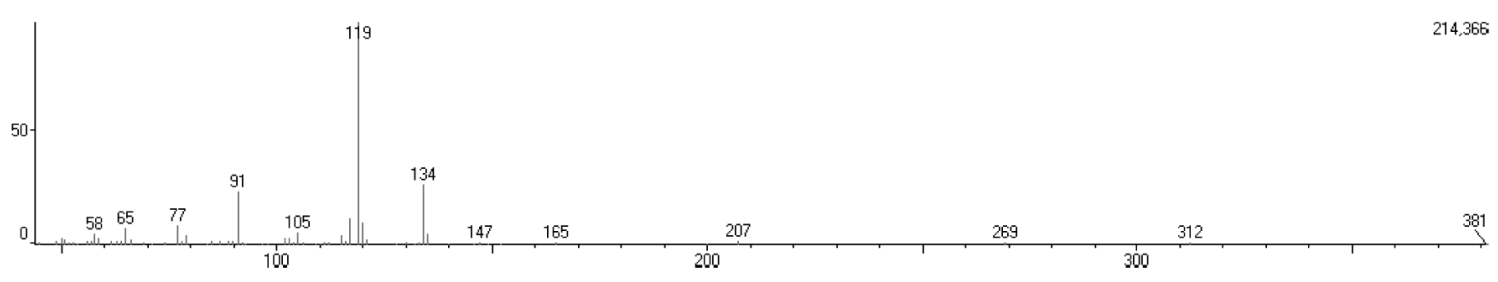

Figure S10. Compound 22, o-cymene (92\%).

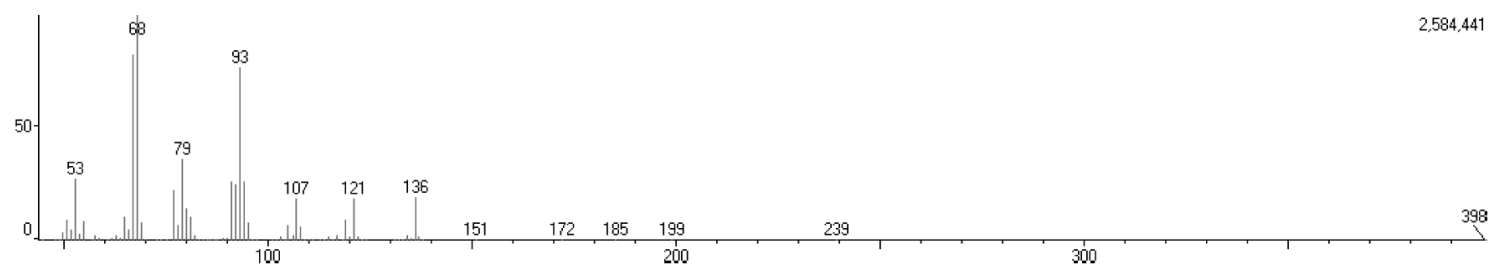

Figure S11. Compound 23, limonene (98\%).

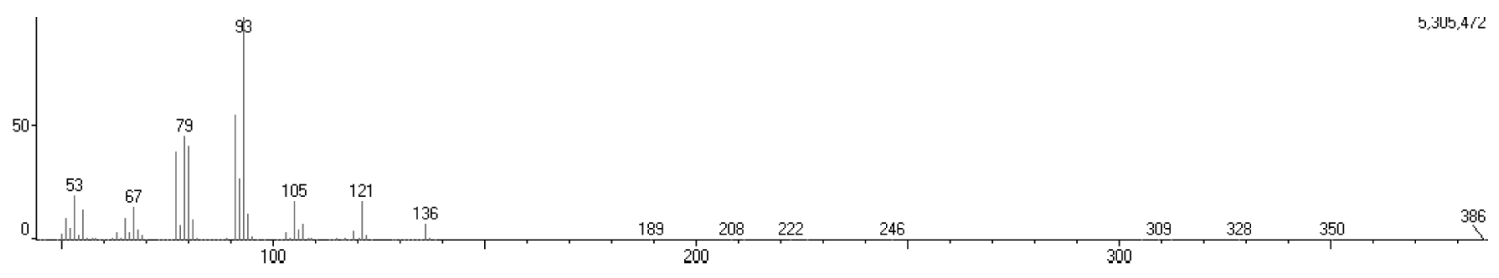

Figure S12. Compound 24, $\Delta$-3-carene (93\%).

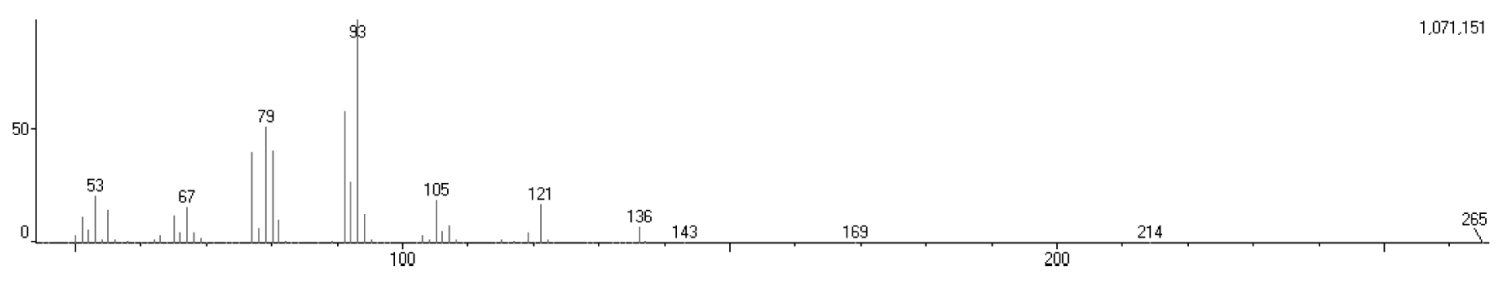

Figure S13. Compound 25, (Z)- $\beta$-ocimene (91\%). 


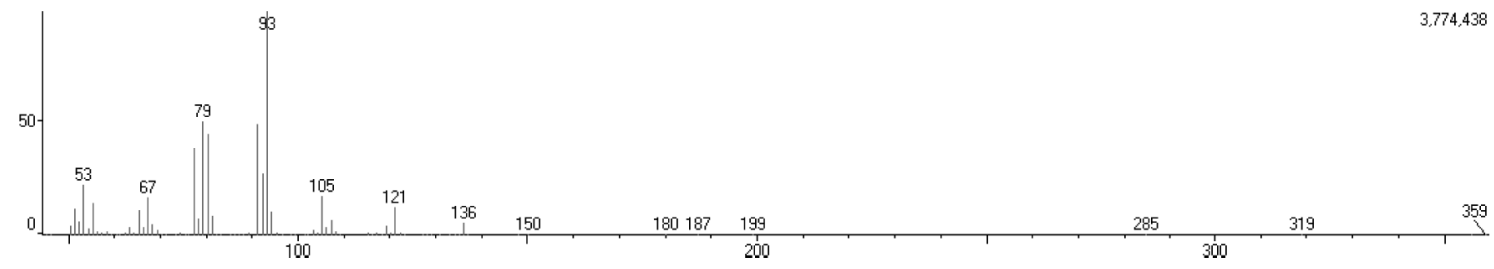

Figure S14. Compound 26, (E)- $\beta$-ocimene (95\%).

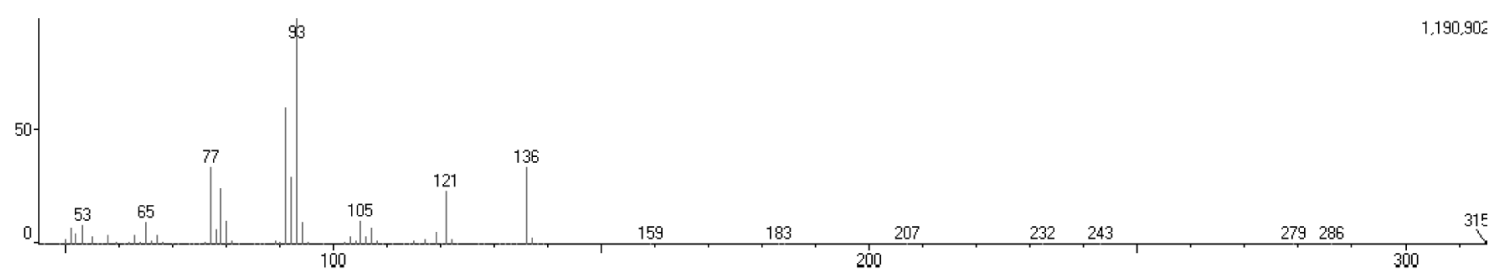

Figure S15. Compound 27, $\gamma$-terpinene (97\%).

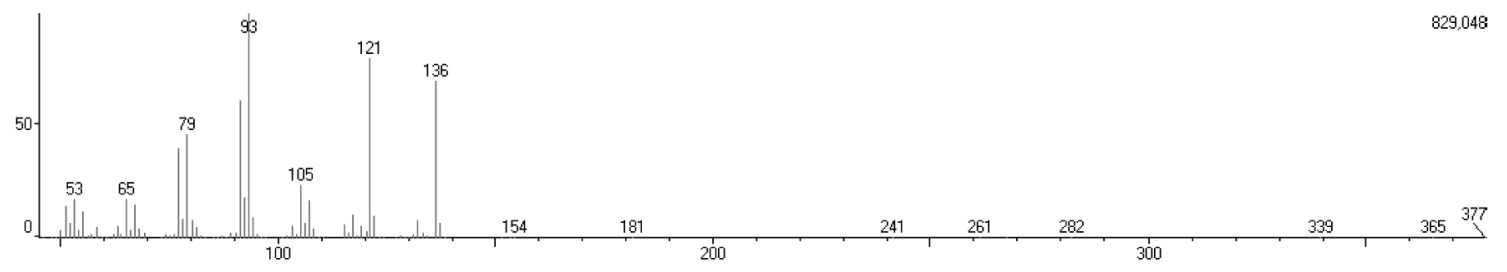

Figure S16. Compound 31, terpinolene (95\%).

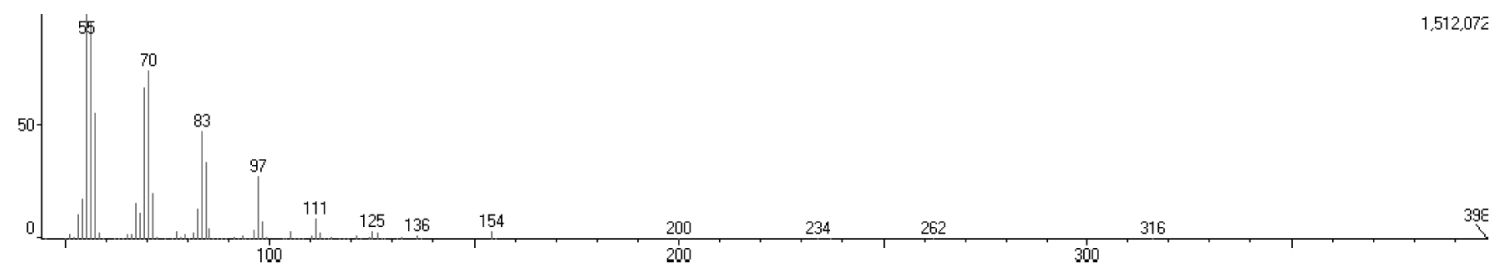

Figure S17. Compound 33, 1-undecene (96\%).

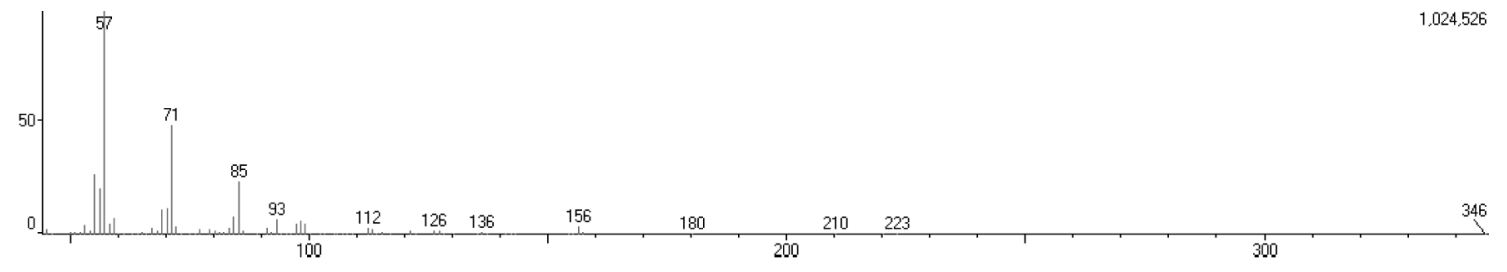

Figure S18. Compound 35, $n$-undecane (91\%). 


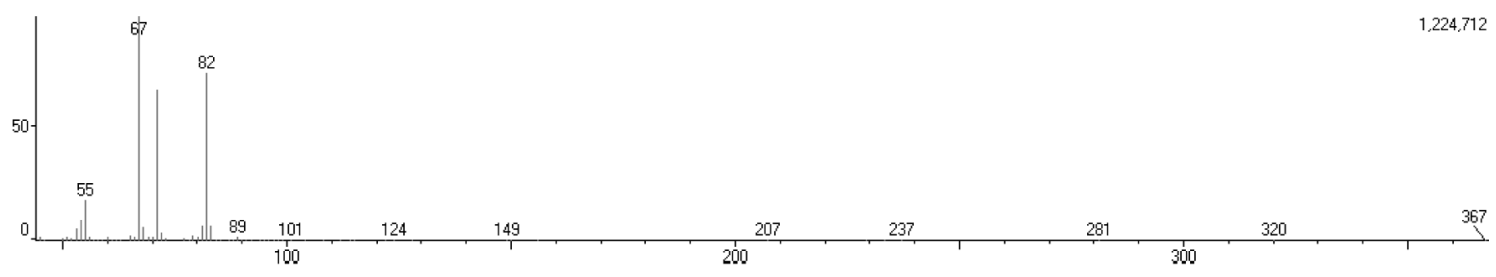

Figure S19. Compound 39, cis-3-hexenyl butanate (98\%).

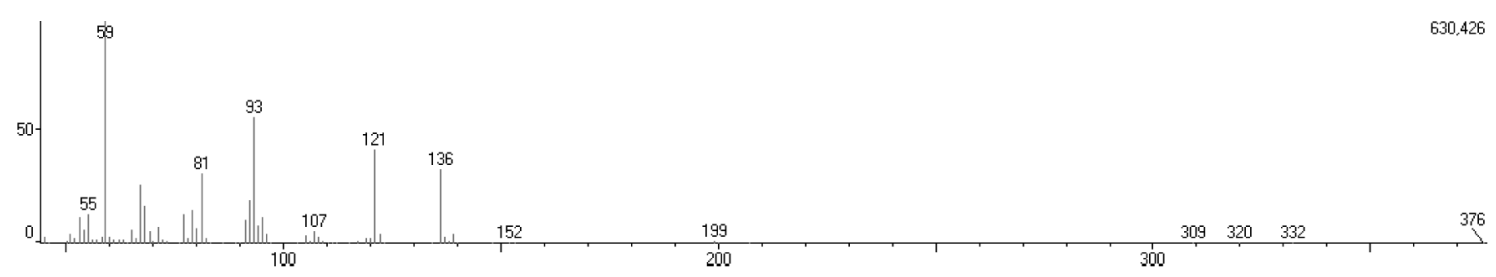

Figure S20. Compound 40, $\alpha$-terpineol (96\%).

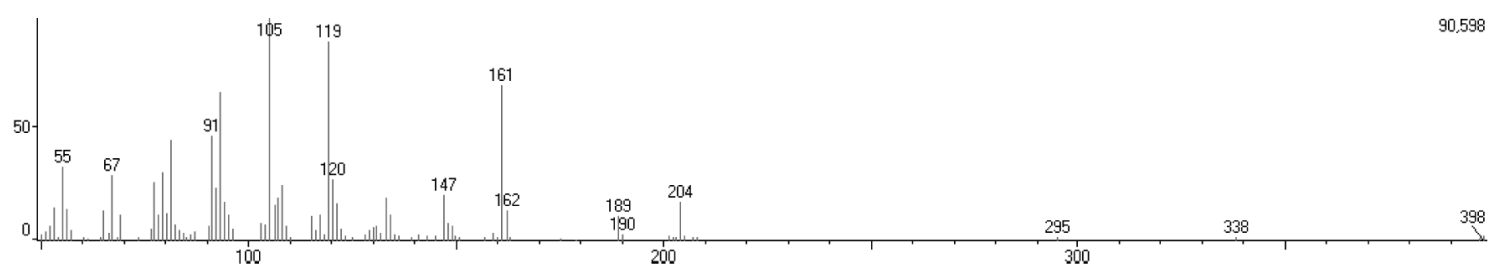

Figure S21. Compound 45, $\alpha$-copaene (89\%).

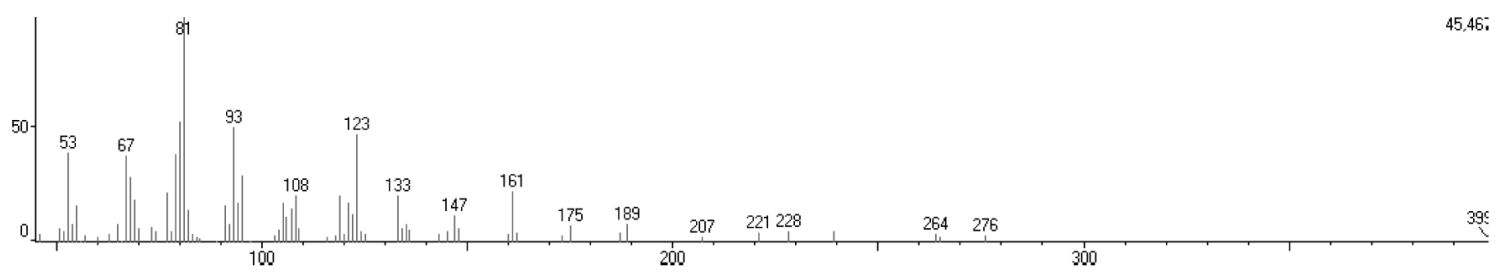

Figure S22. Compound 46, $\beta$-bourbonene (85\%).

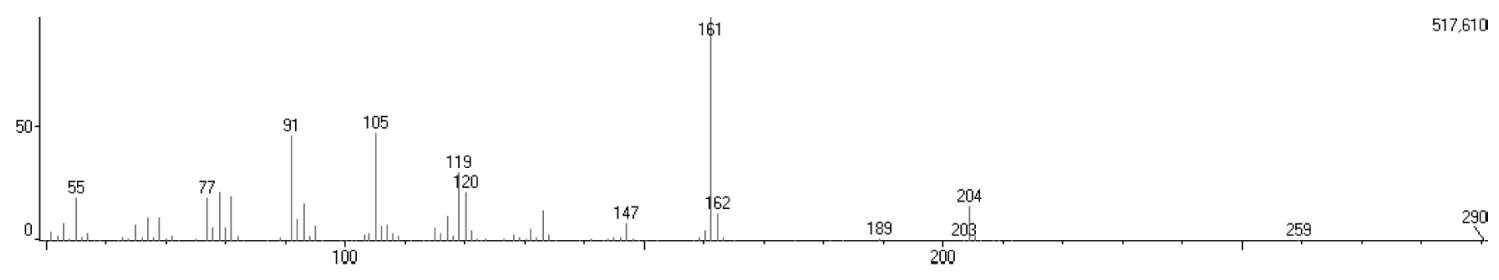

Figure S23. Compound 47, $\beta$-cubebene (94\%). 


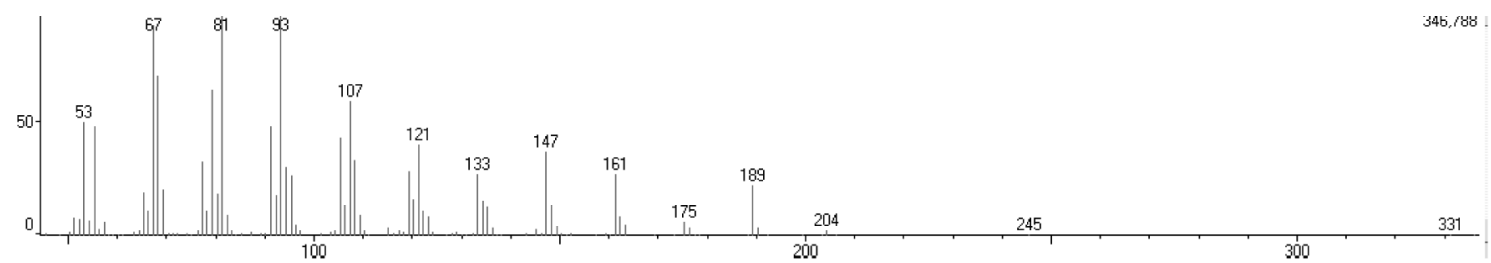

Figure S24. Compound 48, $\beta$-elemene (95\%).

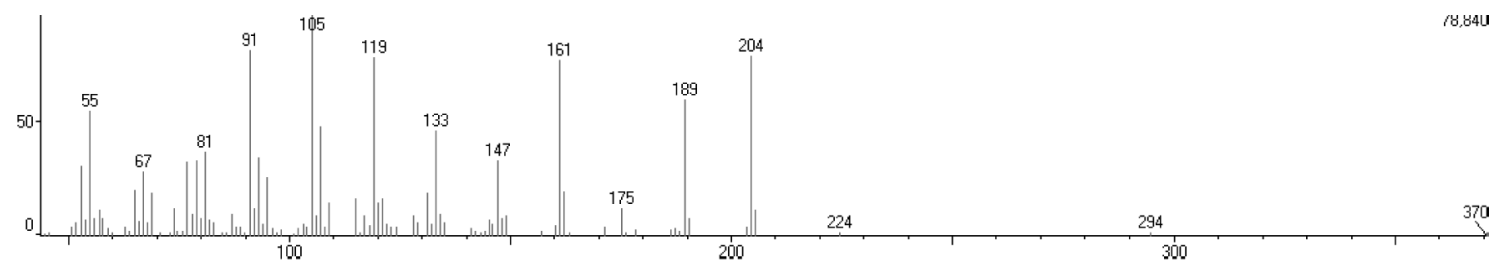

Figure S25. Compound 49, $\alpha$-gurjunene (93\%).

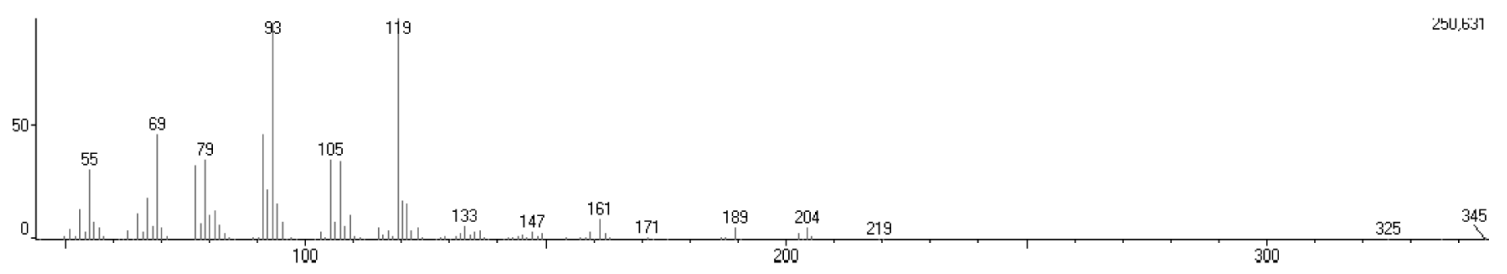

Figure S26. Compound 50, cis- $\alpha$-bergamotene (91\%).

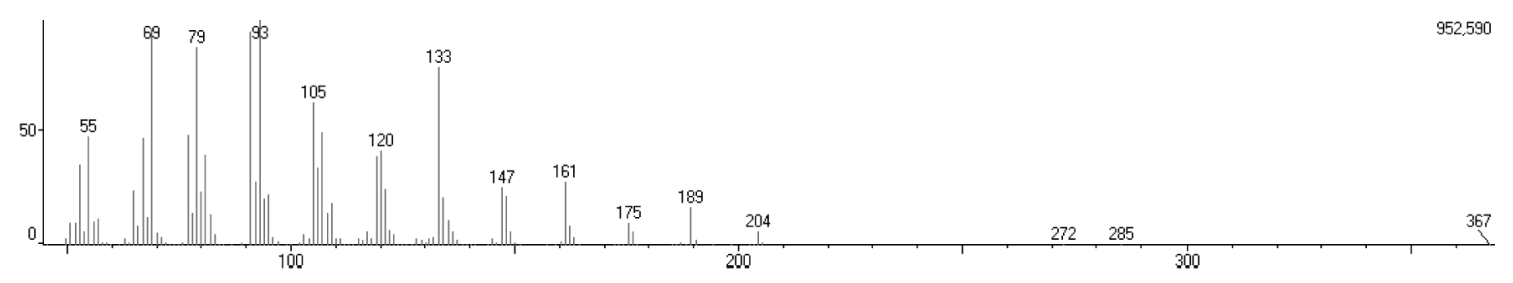

Figure S27. Compound 51, (E)-caryophyllene (95\%).

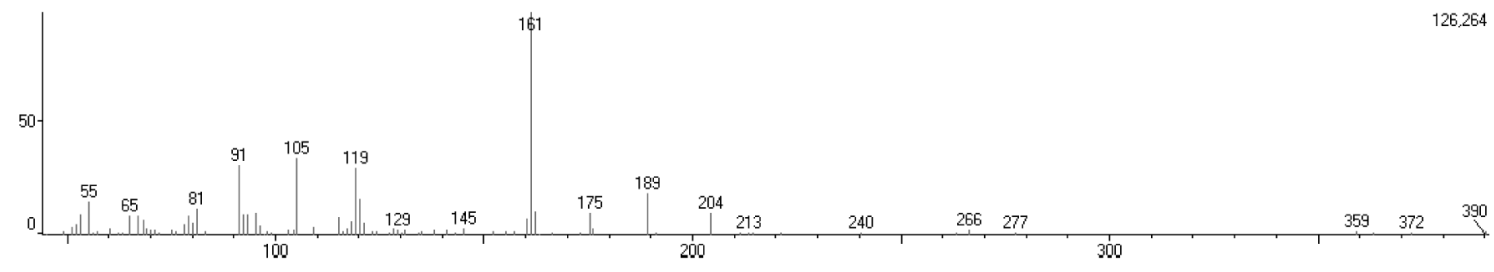

Figure S28. Compound 52, $\beta$-gurjunene (85\%). 


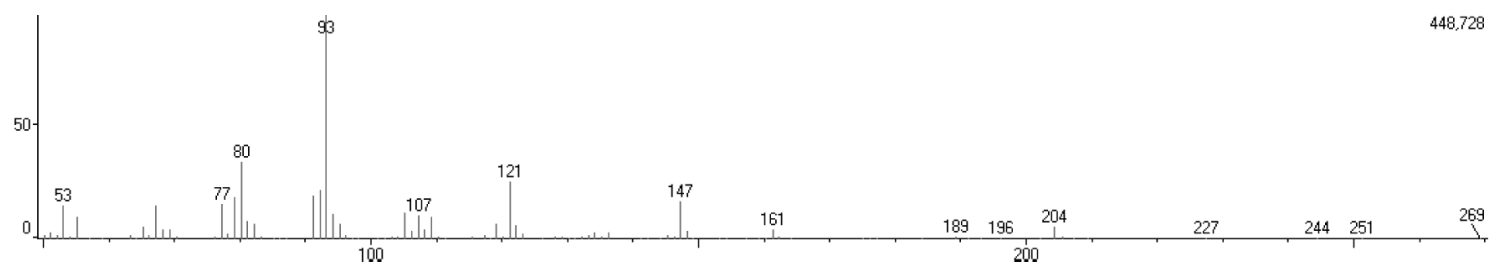

Figure S29. Compound 53, $\alpha$-humulene (96\%).

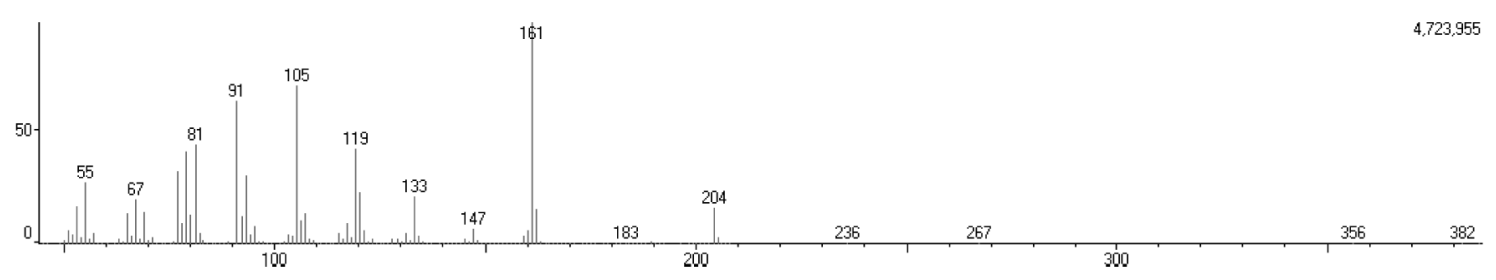

Figure S30. Compound 54, $\gamma$-muurolene (88\%).

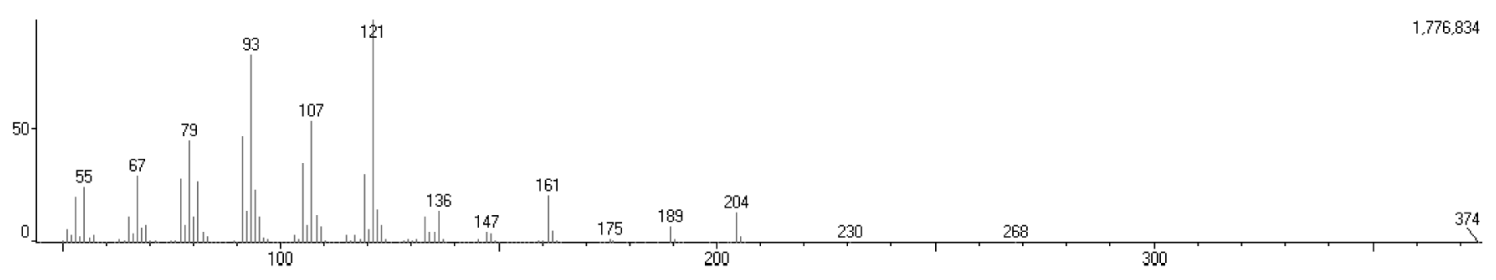

Figure S31. Compound 55, bicyclogermacrene (94\%).

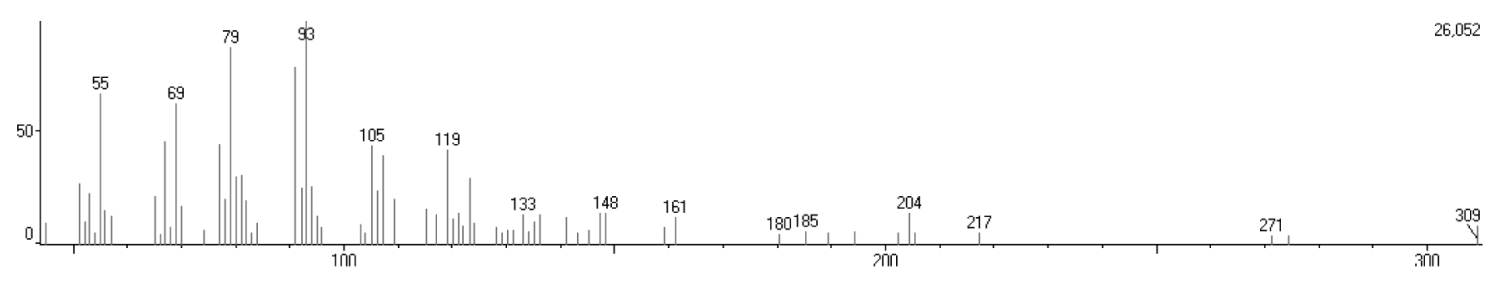

Figure S32. Compound 56, $(E, E)-\alpha$-farnesene (85\%).

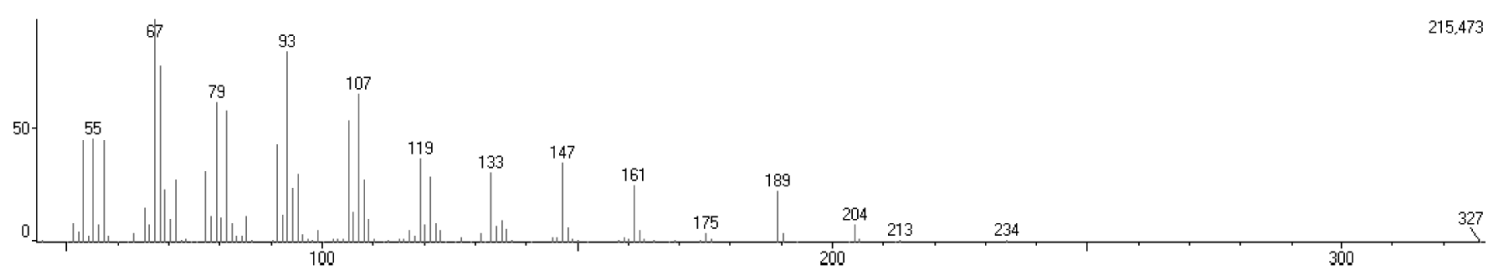

Figure S33. Compound 58, germacrene A (91\%). 


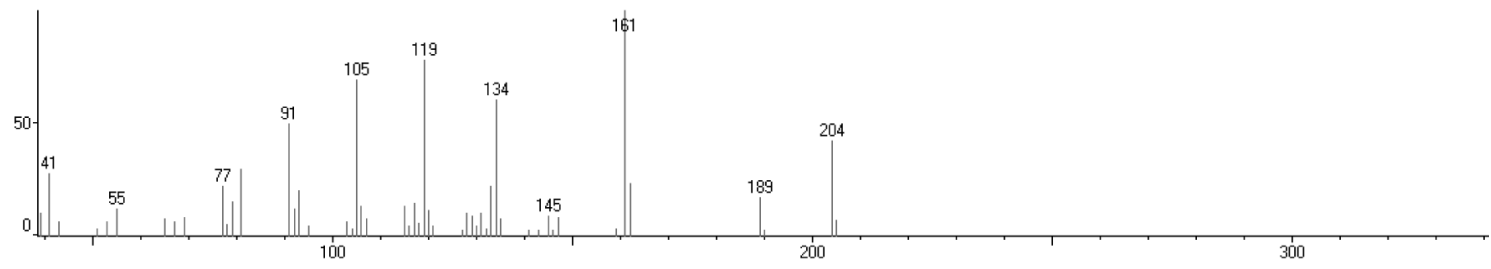

Figure S34. Compound 60, $\gamma$-cadinene (95\%).

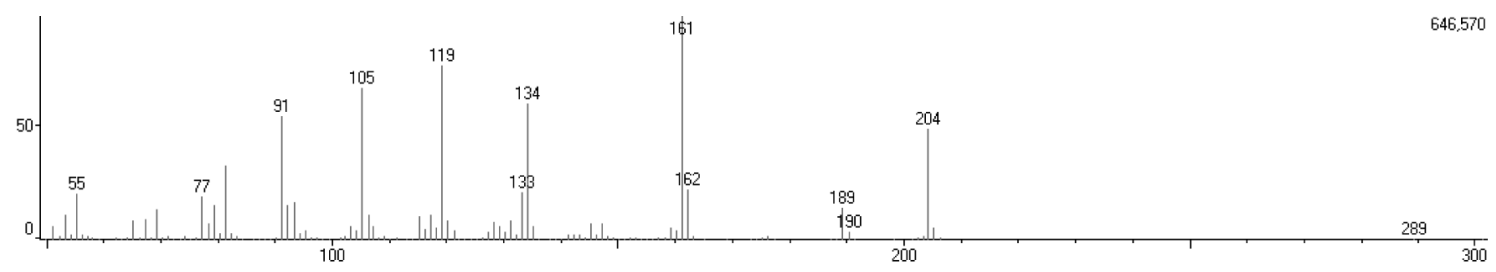

Figure S35. Compound 61, $\delta$-cadinene (96\%).

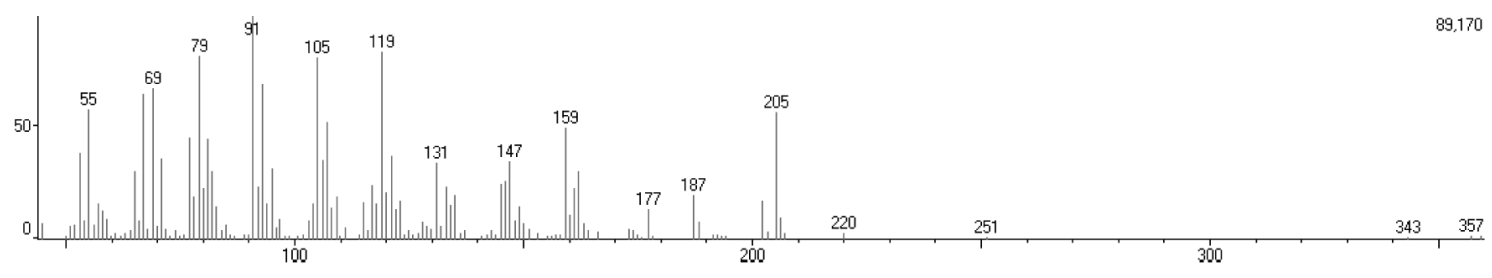

Figure S36. Compound 62, spathulenol (93\%).

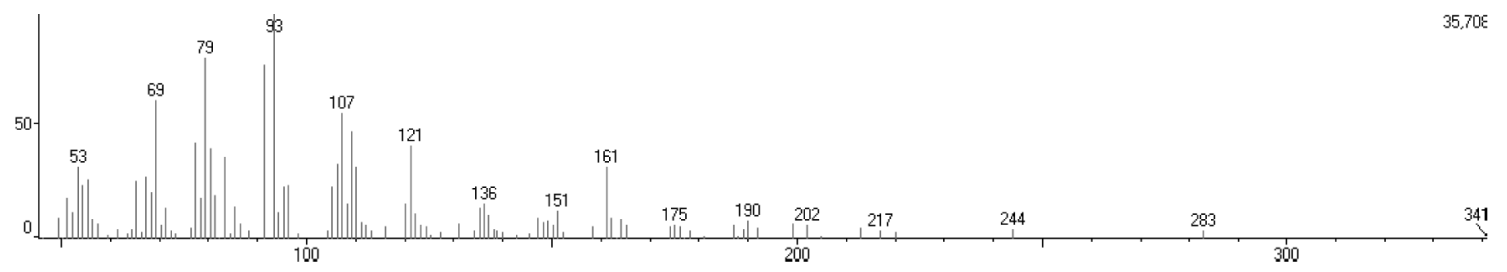

Figure S37. Compound 63, caryophyllene oxide (85\%). 